\title{
Sulphur Dioxide Adsorption on Nickel Smelting Industry in East Luwu Using a Solution of Hydrogen Peroxide
}

\author{
Agus Dina $^{1}$, Muhammad Sjahrul', Muhammad Zakir ${ }^{1}$, Dadang Ahmad Suriamihardja ${ }^{2}$ \\ ${ }^{1}$ Department of Chemistry, Faculty of Mathematics and Natural Science, Hasanuddin University, Makassar, Indonesia \\ ${ }^{2}$ Department of Physics, Faculty of Mathematics and Natural Science, Hasanuddin University, Makassar, Indonesia
}

Email address:

muhammadzakir@gmail.com (M. Zakir)

\section{To cite this article:}

Agus Dina, Muhammad Sjahrul, Muhammad Zakir, Dadang Ahmad Suriamihardja. Sulphur Dioxide Adsorption on Nickel Smelting Industry in East Luwu Using a Solution of Hydrogen Peroxide. American Journal of Environmental Protection. Vol. 5, No. 4, 2016 , pp. 103-108. doi: 10.11648/j.ajep.20160504.15

Received: June 22, 2016; Accepted: July 4, 2016; Published: July 16, 2016

\begin{abstract}
Research on $\mathrm{SO}_{2}$ gas adsorption from emissions of nickel ore industries plant use coal in the smelting process and the production by using $\mathrm{H}_{2} \mathrm{O}_{2}$ as an adsorbent solution. The adsorbent used to reduce the level of $\mathrm{SO}_{2}$ in the air pollution. This study includes the adsorption of $\mathrm{SO}_{2}$ gas of 6 factory chimneys at the nickel ore industry ( 2 dryers, 2 kilns, and 2 furnaces). The results showed that the percentage ratio of the average absorbance between $\mathrm{H}_{2} \mathrm{O}_{2}$ and calcium carbonate in reducing greenhouse gas emissions of $\mathrm{SO}_{2}$ into the air that is $95.00 \%$ : 93.34\%. As for the rest of $\mathrm{SO}_{2}$ gas unadsorbed fixed meet the quality standards specified $\left(750 \mathrm{mg} / \mathrm{m}^{3}\right)$. Batch adsorption was conducted with respect to concentration of adsorbent, the adsorption temperature, and contact time. It was shown that the optimum concentration of adsorbent was $5 \%$, the adsorption temperature was $20^{\circ} \mathrm{C}$, and contact time was 1800 second.
\end{abstract}

Keywords: $\mathrm{SO}_{2}$ Gas, Hydrogen Peroxide, Gas Emission

\section{Introduction}

Total human population that continues to increase accompanied by increased their requirement and their activities. Diverse human activities have negative and positive impact on the environment. One of its negative effects that currently very disturbing is air pollution. According [16], air pollution is the presence of one or more physical substance, chemical, or biological in the atmosphere in an amount which can endanger the health of humans, animals and plants.

One of the substances that can cause air pollution is sulfur. Sulfur compounds in different forms has been known as a major air pollutant industrial areas as a result of burning fossil fuels, and can be derived from volcanic eruptions. In the future, an estimated amount of sulfur discharged into the atmosphere would have increased 10-fold [41]. In the form of gas, $\mathrm{SO}_{2}$ can cause irritation to the lungs that causing hard to breathing especially for people who has asthma, children and the elderly. $\mathrm{SO}_{2}$ is also able to react with other chemical compounds formed sulfate particles that if inhaled can accumulate in the lungs and cause breathing problems, respiratory illnesses, and even death [9].

One of the industries that produce gas emission $\mathrm{SO}_{2}$ is smelting industry Nickel located in Sorowako, East Luwu, South Sulawesi, where the production process is done by burning the raw material in the kiln-firing with coal and produce byproduct that is $\mathrm{SO}_{2}$ [19]. The main problem that causing gas emissions $\mathrm{SO}_{2}$ in the industry is coal as the main fuel, even if used is coal with the best quality (low sulfur content), sulfur dioxide will formed surely and estimated gas emissions $\mathrm{SO}_{2}$ is wasted at least able to reach 13 tons/hour.

Reducing gas emissions $\mathrm{SO}_{2}$ can be done with a wet scrubber systems, combustion flue gas is sprayed with slurry (lime slurry), $\mathrm{Ca}(\mathrm{OH})_{2}$ were able to reduce $\mathrm{SO}_{2}$ emissions of 88.5 thousand tons/year to 4.5 thousand tons/year or absorption $\mathrm{SO}_{2}$ gas approximately 95\% [24] but this process can produce $\mathrm{CO}_{2}$ which is also one of the air pollutants. System wet scrubber also create problems with the chimney because there is spraying a slurry of lime on the chimney wall [43] and this system is costly because the industry had to prepare the land for mining and milling 
limestone as well as land for waste disposal in a large capacity [48].

Based on the description above, it takes a process to reduce gas emissions $\mathrm{SO}_{2}$ that are environmentally friendly and not damage the property industry. As it is known that the gas sulfur dioxide is a colorless, flammable and easily soluble in water, young oxidized, and can react with other compounds. Based on the chemical and physical properties, then the $\mathrm{SO}_{2}$ can be removed by oxidation using oxidizing agent that is hydrogen peroxide and this reaction can produce sulfuric acid compound, so this research is carried out to reduce $\mathrm{SO}_{2}$ gas emissions in the nickel industry located in the east Luwu using hydrogen peroxide.

\section{Experimental}

This research was carried out directly on the nickel smelting industry in East Luwu. This research is qualitative and quantitative research on the amount of $\mathrm{SO}_{2}$ can react with the hydrogen peroxide. Samples emissions of $\mathrm{SO}_{2}$ that get as laboratory scale using an instrument (Figure 1) and there are variation on concentrations, temperature and time of hydrogen peroxide to react with $\mathrm{SO}_{2}$. This process is carried out at the time when the industry is operating in conditions of temperature, flow rate and pressure of maximum emissions. $\mathrm{SO}_{2}$ concentration was measured using a UV - Vis spectrophotometer.

\subsection{Instrument}

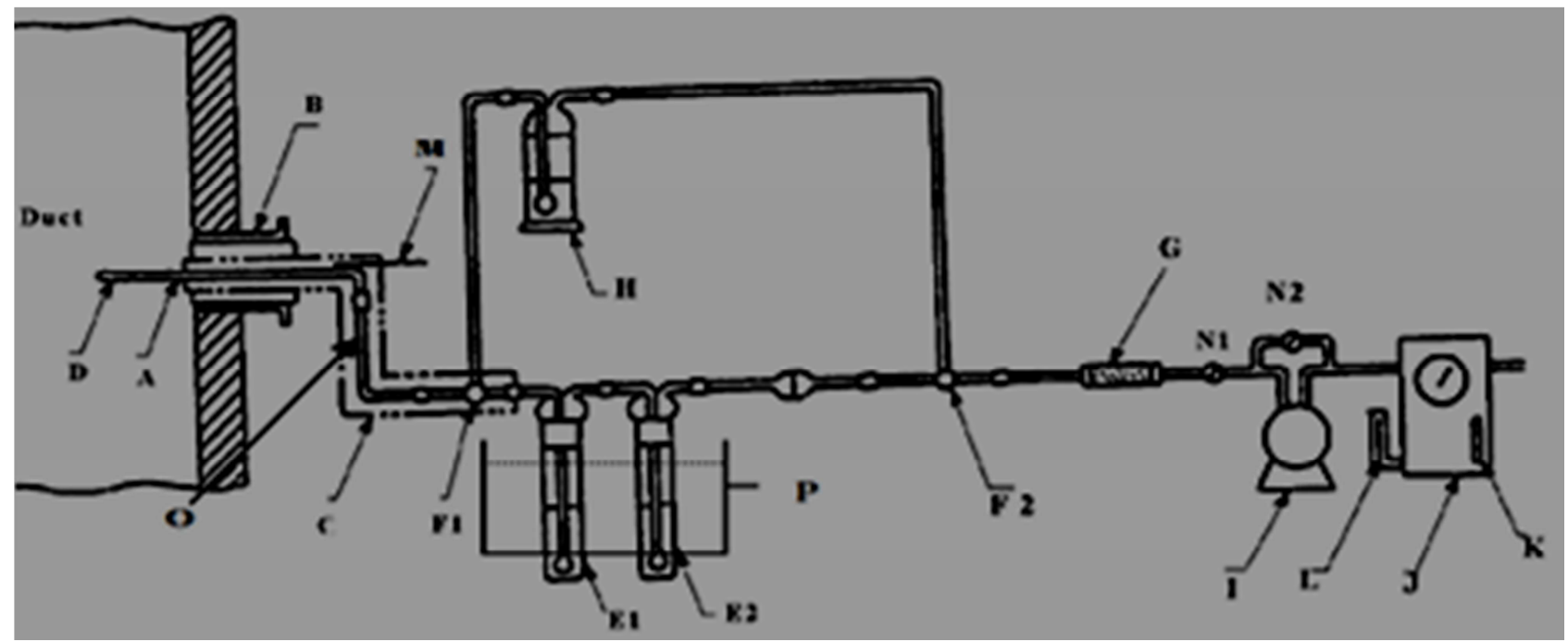

Figure 1. The series of instrument of $\mathrm{SO}_{2}$ sampling.

Description of Instrument:

A: Pipe sampling test;

B: Flange;

$\mathrm{C}$ : heater element;

D: glass wool;

E1, E2: adsorption bottle of $250 \mathrm{~mL}$;

F1,F2: junction three-cock;

G: drying tube;

$\mathrm{H}$ : wash bottle containing the adsorbent solution;

I: aspirator pump;

$\mathrm{J}$ : gas meter (capacity $1 \mathrm{~L}$ - 5 L per circle);

$\mathrm{K}$ : gas meter thermometer;

L: manometer;

M: thermometer;

N1: the cover faucet;

$\mathrm{N} 2$ : faucet flow rate regulator:

$\mathrm{O}$ : rubber pipe (flurorubber);

$\mathrm{P}$ : cooling container.

\subsection{Material}

The materials used in this research are hydrogen peroxide $30 \%, \mathrm{NaCl}, \mathrm{HCl}(37 \% \mathrm{w} / \mathrm{v})$, Glycerol, Barium chloride $\left(\mathrm{BaCl}_{2}\right)$, Sulfuric acid $\left(\mathrm{H}_{2} \mathrm{SO}_{4}\right) 0,1 \mathrm{~N}$; Sodium tetraborate (boraks, $\mathrm{Na}_{2} \mathrm{~B}_{4} \mathrm{O}_{7} \cdot 10 \mathrm{H}_{2} \mathrm{O}$ ) $0,1 \mathrm{~N}$; Indicator $\mathrm{SM}$ (sindur methyl) orMO (methyl orange) and Field blank solution.

\section{Results and Discussion}

Sampling and adsorption exhaust gas emissionsindustry conducted for twelve days in May 2015. The sampling is done where the condition of each chimney in a state of maximum 6 industrial chimney, each on 2 chimneydryer, 2 chimney Kiln, and 2chimney furnace. The sampling 
technique uses a series of side tool probe, vacuum for sucking in air emissions and a series of impinger a place for adsorbent solution (hydrogen peroxide). To view the results adsorption of $\mathrm{SO}_{2}$ gas, then conducted sample analysis in
Laboratory Technical Implementation Unit of the Environment Agency of South Sulawesi province. Description of adsorption results concentration of $\mathrm{SO}_{2}$ of each the chimney can be seen in the following chart.

Table 1. Results of adsorption concentration of $\mathrm{SO}_{2}$ gas in chimneys emissions based on variations concentration of adsorbent solution.

\begin{tabular}{|c|c|c|c|c|c|c|c|}
\hline \multirow{3}{*}{ No } & \multirow{3}{*}{ Concentration (\%) } & \multicolumn{6}{|c|}{ Results (mg// $\left.\mathbf{M}^{3}\right)$} \\
\hline & & \multicolumn{6}{|c|}{ Hydrogen peroxide } \\
\hline & & Dryer 1 & Dryer 2 & Kiln 1 & Kiln 2 & Furnace 1 & Furnace 2 \\
\hline 1 & 1 & $2,585.25$ & $3,185.07$ & $4,093.89$ & $3,031.75$ & $6,345.13$ & $6,495.09$ \\
\hline 2 & 2 & $4,558.59$ & $4,383.21$ & $4,717.91$ & $3,432.83$ & $6,462.34$ & $6,290.94$ \\
\hline 3 & 3 & $5,545.59$ & $4,390.07$ & $4,949.44$ & $3,790.89$ & $8,414.79$ & $8,052.81$ \\
\hline 4 & 4 & $4,824.26$ & $5,468.10$ & $6,067.79$ & $4,548.50$ & $8,570.97$ & $8,406.47$ \\
\hline 5 & 5 & $5,562.36$ & $5,610.57$ & $7,805.51$ & $6,099.64$ & $10,501.50$ & $10,590.40$ \\
\hline
\end{tabular}

Table 2. Results of adsorption concentration of $\mathrm{SO}_{2}$ gas in chimneys emissions by temperature variations of adsorbent solution.

\begin{tabular}{|c|c|c|c|c|c|c|c|}
\hline \multirow{3}{*}{ No } & \multirow{3}{*}{ Temp. $\left({ }^{\circ} \mathrm{C}\right)$} & \multicolumn{6}{|c|}{ Results (mg//M ${ }^{3}$ ) } \\
\hline & & \multicolumn{6}{|c|}{ Hydrogen peroxide } \\
\hline & & Dryer 1 & Dryer 2 & Kiln 1 & Kiln 2 & Furnace 1 & Furnace 2 \\
\hline 1 & 20 & $5,328.14$ & $5,377.72$ & $6,674.04$ & $5,316.34$ & $9,613.78$ & $10,015.3$ \\
\hline 2 & 25 & $4,526.98$ & $4,988.47$ & $6,466.24$ & $4,381.93$ & $9,603.76$ & $8,610.69$ \\
\hline 3 & 30 & $4,083.60$ & $4,918.19$ & $6,006.50$ & $3,854.37$ & $8,433.09$ & $8,563.33$ \\
\hline 4 & 35 & $3,437.75$ & $4,765.20$ & $4,018.89$ & $3,694.13$ & $7,257.47$ & $6,373.46$ \\
\hline 5 & 40 & $2,780.29$ & $3,333.34$ & $3,573.66$ & $2,852.99$ & $6,229.25$ & $6,236.93$ \\
\hline
\end{tabular}

Table 3. Results of adsorption concentration of $\mathrm{SO}_{2}$ gas in chimneys emissions based on time variation of adsorbent solution.

\begin{tabular}{|c|c|c|c|c|c|c|c|}
\hline \multirow{3}{*}{ No } & \multirow{3}{*}{ Time (second) } & \multicolumn{6}{|c|}{ Results (mg// $\left.\mathbf{M}^{3}\right)$} \\
\hline & & \multicolumn{6}{|c|}{ Hydrogen peroxide } \\
\hline & & Dryer 1 & Dryer 2 & Kiln 1 & Kiln 2 & Furnace 1 & Furnace 2 \\
\hline 1 & 600 & $2,880.02$ & $2,650.28$ & $3,698.88$ & $2,796.12$ & $5,789.36$ & $4,584.16$ \\
\hline 2 & 900 & $3,389.42$ & $3,665.24$ & $4,864.09$ & $3,222.10$ & $6,741.13$ & $5,528.04$ \\
\hline 3 & 1200 & $4,673.73$ & $4,305.88$ & $5,552.45$ & $4,538.86$ & $8,455.43$ & $8,149.12$ \\
\hline 4 & 1500 & $4,937.86$ & $5,097.07$ & $6,559.05$ & $5,267.34$ & $9,685.90$ & $8,101.28$ \\
\hline 5 & 1800 & $5,447.36$ & $5,585.66$ & $7,466.57$ & $6,019.59$ & $10,271.01$ & $10,249.52$ \\
\hline
\end{tabular}

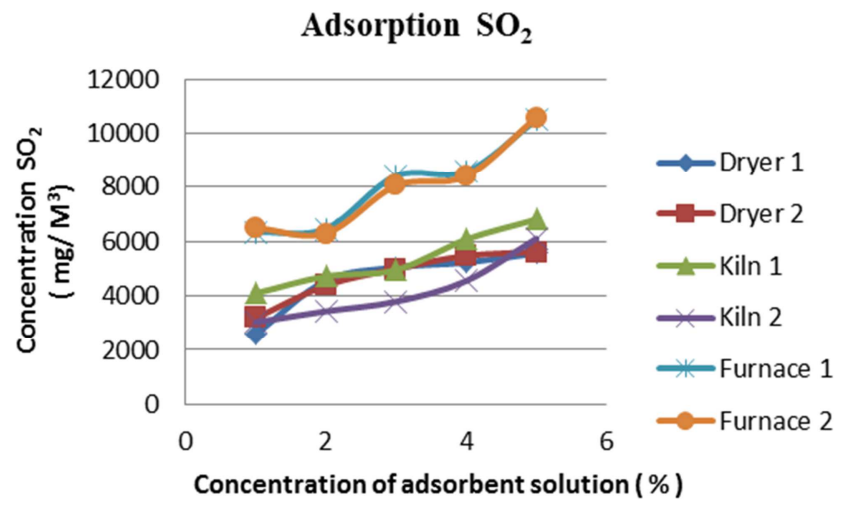

Figure 2. Results of adsorption concentration of $\mathrm{SO}_{2}$ gas in chimneys emissions based on variations concentration of adsorbent solution.

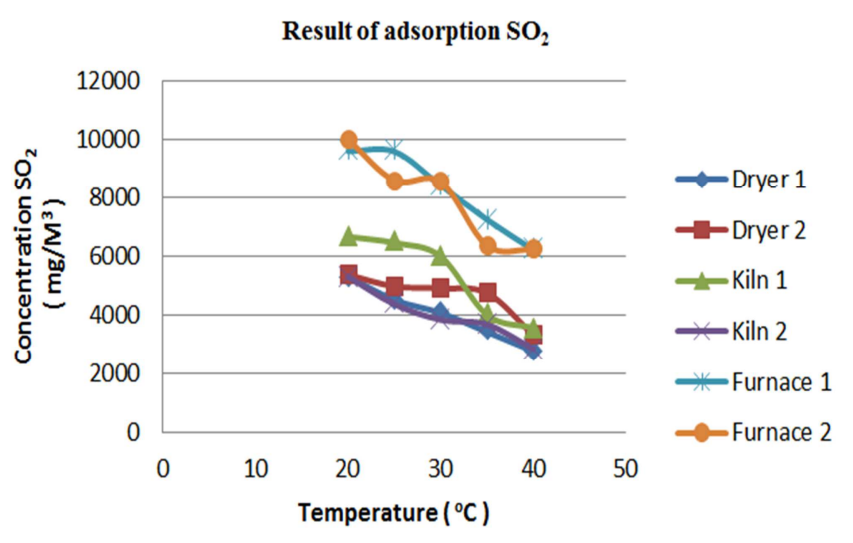

Figure 3. Results of adsorption concentration of $\mathrm{SO}_{2}$ gas in chimneys emissions by temperature variations of adsorbent solution. 


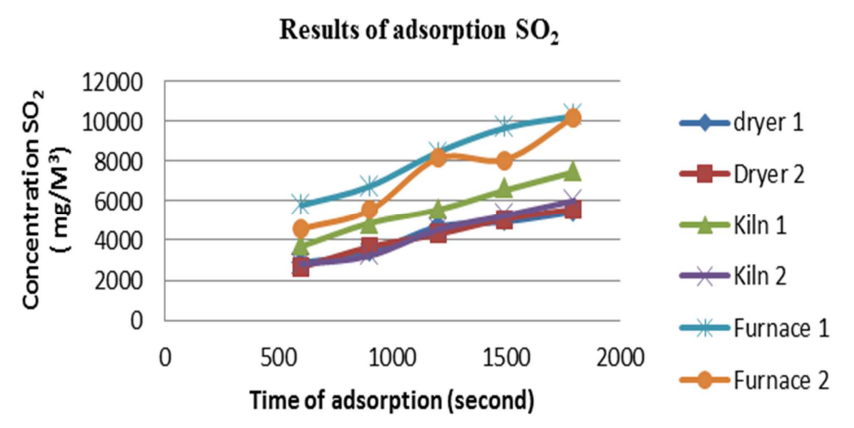

Figure 4. Results of adsorption concentration of $\mathrm{SO}_{2}$ gas in chimneys emissions based on time variation of adsorbent solution.

Based on the test data exhaust gas of $\mathrm{SO}_{2}$ is absorbed by the hydrogen peroxide from chimneys emissions at dryer 1 and 2 ; kiln 1 and 2 ; and furnace 1 and 2 , increased concentration of maximum adsorption indicated in the treatment adsorbent solution on the condition of $20^{\circ} \mathrm{C}$, with a concentration of 5\% and length taking 1800 seconds. Results achieved in the adsorption capability of the accumulation of means as follows:

1. Dryer 1, cylindrical chimney with a height of 61.6 meters with a diameter of 4 meters at coordinates $02^{\circ} 34^{\prime} 8.3^{\prime \prime}$ LS and BT $121^{\circ} 22^{\prime} 38.9^{\prime \prime}$ with a gas flow rate $327.82 \mathrm{~m}^{3} / \mathrm{sec}$. Conditions of the emission gas temperature $\quad 140^{\circ} \mathrm{C}, \quad$ resulting adsorption $5479.29 \mathrm{mg} / \mathrm{m}^{3}, 4623.62$ tons $/$ month or $96.62 \%$.

2. Dryer 2, cylindrical chimney with a height of 60.9 meters with 3.9 meter cross-sectional area at coordinates $02^{\circ} 34^{\prime} 8.4^{\prime \prime} \mathrm{LS}$ and BT $121^{\circ} 22^{\prime} 39.5^{\prime \prime}$ with a gas flow rate $312.74 \mathrm{~m}^{3} / \mathrm{sec}$ in the emissions gas temperature conditions $\pm 140^{\circ} \mathrm{C}$ produce adsorption $5361.79 \mathrm{mg} / \mathrm{m}^{3}$ or 4348.41 tons/month or $90.87 \%$.

3. Kiln 1 (Reduced 1) is a cylindrical chimney with a height of 61 meters with 2.9 meter cross-sectional area at coordinates $02^{\circ} 34^{\prime} 08.4 \mathrm{LS}$ "and BT $121^{\circ} 22^{\prime} 38.8^{\prime \prime}$ gas flow rate $234.87 \mathrm{~m}^{3} / \mathrm{sec}$ in the emission gas temperature conditions $\pm 168^{\circ} \mathrm{C}$ produces adsorption 4454.99 tons $/$ month or $7315.25 \mathrm{mg} / \mathrm{m}^{3}$ or $90.78 \%$.

4. Kiln 2 (Reduction 2) is a cylindrical chimney with a height of 62 meters with 2.9 meter cross-sectional area at coordinates $02^{\circ} 34^{\prime} 09.1 \mathrm{LS}$ "and BT $121^{\circ} 22^{\prime} 41.4^{\prime \prime}$ with a gas flow rate $291.39 \mathrm{~m}^{3} / \mathrm{sec}$ in the emissions gas temperature conditions $\pm 168^{\circ} \mathrm{C}$ resulted adsorption 4387.95 tons/month or $5811.85 \mathrm{mg} / \mathrm{m}^{3}$ or $89.41 \%$.

5. Furnace 1, cylindrical chimney with a height with a height of 61 meters with 4.1 meter cross-sectional area at coordinates $02^{\circ} 34^{\prime} 09.4 \mathrm{LS}$ "and BT $121^{\circ} 22^{\prime} 42.9^{\prime \prime}$ with a gas flow rate $291.39 \mathrm{~m}^{3} / \mathrm{sec}$ in the emissions gas temperature conditions $\pm 200^{\circ} \mathrm{C}$ produce adsorption 4720.00 tons/month or $10128.76 \mathrm{mg} / \mathrm{m}^{3}$ or $96.18 \%$.

6. Furnace 2, cylindrical chimney with a height of 61 meters with 4.1 meter cross-sectional area at coordinates $02^{\circ} 40^{\prime} 15.1 \mathrm{LS}$ "and BT $121^{\circ} 10^{\prime} 25.2^{\prime \prime}$. with a gas flow rate $291.39 \mathrm{~m}^{3} / \mathrm{sec}$ in the emissions gas temperature conditions $\pm 200^{\circ} \mathrm{C}$ produce adsorption 4720.84 tons/month or $10285.05 \mathrm{mg} / \mathrm{m}^{3}$ or $96.19 \%$.
Direct measurements of $\mathrm{SO}_{2}$ gas emissions conducted in the same monthof the dryer 1 with a gas flow rate 239.39 $\mathrm{m}^{3} / \mathrm{sec}$, dryer 2 with a gas flow rate $212.39 \mathrm{~m}^{3} / \mathrm{sec}$ produce an average of test results to produce \pm 4785.43 tons/month or equivalent to $8692.64 \mathrm{mg} / \mathrm{m}^{3}$, while from kiln 1 with a flow rate $171.52 \mathrm{~m}^{3} / \mathrm{sec}$ and kiln 2 with a flow rate $223.94 \mathrm{~m}^{3} / \mathrm{sec}$ produce an average of \pm 4907.70 tons/month or equivalent to $9622.94 \mathrm{mg} / \mathrm{m}^{3}$. Furnace 1 with a gas flow rate $236.63 \mathrm{~m}^{3} / \mathrm{sec}$ and furnace 2 with a gas flow rate $170 \mathrm{~m}^{3} / \mathrm{sec}$ also resulted in an average concentration \pm 4907.7 tons/month or equivalent to $9259.81 \mathrm{mg} / \mathrm{m}^{3}$.

Gas emissionsthat are not adsorbed from flue dryer 1 is 161.81 tons $/$ month or $190.59 \mathrm{mg} / \mathrm{m}^{3}$ or $3.38 \%$, dryer 2 is 437.02 tons $/$ month or $538.87 \mathrm{mg} / \mathrm{m}^{3}$ or $9.13 \%$, kiln 1 was 452.71 tons $/$ month or $743.37 \mathrm{mg} / \mathrm{m}^{3}$ or $9.22 \%$, kiln 2 was 519.75 tons $/$ month or $688.41 \mathrm{mg} / \mathrm{m}^{3}$ or $10.59 \%$, furnace 1 was 187.70 ton/month or $402.79 \mathrm{mg} / \mathrm{m}^{3}$ or $3.82 \%$, and furnace 2 was 186.86 tons $/$ month or $407.10 \mathrm{mg} / \mathrm{m}^{3}$ or $3.81 \%$.

The results showed that the higher the temperature of the solution is getting lower to adsorb exhaust gas emissions, the lower the flow rate of the exhaust gas is getting greater the ability reaction of adsorbent and the nature of the gases emitted fluctuations in temperature, pressure and flow rate as well as the turbulence also affects the absorption of gas emissions factory chimneys.

Based on data from previous research using a slurry of lime (calcium hydroxide) which is able to adsorb sulfur dioxide by $95 \%$ equal to the adsorption ability of hydrogen peroxide that is $94.85 \%$ from industrial sources of nickel.

\section{Conclusions}

This result of this study that is comparison of percentage of the average adsorption accumulation between adsorbent solution using a solution of hydrogen peroxide and calcium carbonate slurry to reduce sulfur dioxide emissions into the ambient air show results approximately equal to the lime slurry that is $95.00 \%: 93.34 \%$. The adsorption concentration of $\mathrm{SO}_{2}$ greater if conditions adsorbent greater concentration, then the lower the temperature and the longer the adsorption time. Emissions of the six chimneys that are not adsorbed, they meet the standards set. under the rules of the Governor Number 69 Year 2010 on the quality standard emissions of $\mathrm{SO}_{2} 750 \mathrm{mg} / \mathrm{m}^{3}$, means that hydrogen peroxide as a adsorbent solution viable as an alternative instead of calcium carbonate.

\section{References}

[1] Ahmed, I. B., P. K. Gbor, and C. Q. Jia, "Aqueous sulfur dioxide leaching of $\mathrm{Cu}, \mathrm{Ni}, \mathrm{Co}, \mathrm{Zn}$, and $\mathrm{Fe}$ from smelter slag in absence of oxygen," Can. J. Chem. Eng. 78(A) 694-703 (2000).

[2] Ahmed, I. B., P. K. Gbor, and C. Q. Jia, "Effect of $\mathrm{O}_{2}$ on aqueous $\mathrm{SO}_{2}$ leaching of $\mathrm{Co}, \mathrm{Cu}$, and $\mathrm{Ni}$ from discard smelter slag," Can. J. Chem. Eng. 80(3) 410-420 (2002). 
[3] Arun Kumar Sharma, D. S. N. Prasad, ShvetaAcharya, and Rashmi Sharma. Utility and Application of FGD System (Flue Gas Desulphurization) in Chemical and Environmental Engineering. International Journal of Chemical Engineering and Applications, Vol. 3, No. 2, April 2012.

[4] Bhamidipati V. N. and W. C. Gibson (2003), Considerations for Low Sulfur Coal Blending, B. L. England Station, US.

[5] Cahyadi, 2006. Strategi menurunkan emisi $\mathrm{SO}_{2}$ pada PLTU batubara yang tidak memiliki fasilitas desulfurisasi. Jurnal Ilmiah Teknologi Energi, Vol.1, No.2. ISSN 1858-3466.

[6] Cooper dan Alley, 1986. Air Pollution Control: A Design Approach. PWS Engineering, Boston.

[7] Carn, S. A., Krueger, A. J., Krotkov, N. A., Yang, K., and Levelt, P. F., 2007, Sulfur dioxide emissions from Peruvian copper smelters detected by the Ozone Monitoring Instrument, Geophys. Res. Lett., 34, L09801.

[8] Davis and Cornwell, 1991. Introduction to Environmental Engineering. Second Edition.

[9] Direktorat Batubara-ESDM, 2005. Data spesifikasi batubara perusahaan tambang batubara Indonesia tahun 2004, Jakarta, Indonesia.

[10] ENV, Updated Report: Sulfur Dioxide Abatement Project Comparative Impact Assessment, 10 Februari 2011.

[11] FastiaWininda dan Puji Lestari, 2006. Analisis karakteristik emisi cerobong dalam fasa gas pada industri semen yang menggunakan bahan bakar alternatif. Environmental Engineering Study Program. Faculty of Civil and Environment Engineering, ITB, Indonesia.

[12] Ferron, C. J., 2008, Sulfur dioxide: a versatile reagent for the processing of cobaltic oxide minerals, Journal of Metals, 60(10), 50-54.

[13] Habashi, F., 1976, Reduction of sulfates by hydrogen, Can. J. Chem, 54: 3646-3650.

[14] Hatch., Carbon Footprint of $\mathrm{SO}_{2}$ Scrubbing, PT. INCO, November 2010.

[15] Hatfield, 2010, Distribution And Diversity Of Lichens And Bryophytes In Sorowako Area And Potential For Use As Indicators Of Air Quality.

[16] Hutagalung, M. 2008. TeknologiPengolahanLimbah Gas. Tersedia: http://majarimagazine.com/2008/01/teknologipengolahan-limbahgas/.

[17] Ilari Ekman and Antti Ahti, 2004, Experiences of LIFAC FGD In Chinese Boiler, Proceeding China International Exhibition \& Conference on SOx and NOx Reduction 2004, Beijing, P.R. China.

[18] Kim Y. Z., J. K. Han, H. K. Hong, S. K. Lee, 1999, A Coal Blending Experience for the Reduction of Power Plant SOx Emission, Samchonpo Thermal Power Site Division, KEPCO, KyongNam Province, Korea.

[19] Laporanpelaksanaan RKL-RPL PT. INCO.2006, 2008, 2009, 2010.

[20] Martindale: The Complete Drug Reference $35^{\text {th }}$ edition 2. AHFS 2008, elect. version 3. e-MIMS Australia, 2003 $2006 / 2007$ p. 914 . BNF $54^{\text {th }}$ edition, elect. version. 5. DOEN 2008, hal.39, 68 .
[21] McDonald, R. G., and B. 1. Whittington, 2008, Atmospheric acid leaching of nickel laterites review. Part I. Sulfuric acid technologies, Hydrometallurgy, 91 (1), 35-55.

[22] Mudd, Gavin M., 2009, Nickel sulfide versus laterite: The harde sustainability challenge remains, proceedings of the $48^{\text {th }}$ Annual Conference of Metallurgists, Canadian Metallurgical Society, Sudbury, Ontario, Canada.

[23] Nur, M., Wirawan, B. Y., Wijaya, W. A., Suseno, A., Sumariyah, 2006, Pereduksian COx, NOx, SOx, HC, Dari Kendaraan Bermotor Dengan Menggunakan Plasma Nontermik, Berkala Fisika, 9 (4), 209-219 ISSN: 1410-9662.

[24] Marosin, R., dan Anam, A., 2004, Karakteristik Emisi Gas Buang Insenerator Medis di Rumah Sakit Jiwa Dadi Makassar Sulawesi Selatan, Jurnal Teknologi Lingkungan, 5 (1).

[25] Mulaudzi, N., and T. Mahlangu, 2009, Oxidative precipitation of $\mathrm{Mn}(1 \mathrm{l})$ from cobalt leach solutions using dilute $\mathrm{SO}_{2} /$ air mixture, paper presented at Hydrometallurgy Conference, The Southern African Institute of Mining and Metallurgy.

[26] Nolan P. S., 1998, Flue Gas desulfurization in China, Babcock \& Wilcox, International Electric Power for China.

[27] Nolan P. S., 2000, Flue Gas Desulfurization, Technologies for Coal-Fired Power Plant, Low Rank Coal Utilization, ICS, Jakarta.

[28] Nuning E. K. dan R. Azizah, 2005, Pengaruh Penggunaan Cerobong Asap Model "Water Spons Filter" (WSF) Terhadap Penurunan Kadar $\mathrm{SO}_{2}$ Pada Industri Tahu di Sukun, Malang.

[29] Peraturan Presiden No. 61 tahun 2011 tentang Rencana Aksi Nasional Penurunan Emisi Gas Rumah Kaca.

[30] Tim Perumus Gubernur, 2010, Peraturan gubernur Sulawesi Selatan No. 69 tahun 2010 tentang baku mutu dan kriteria kerusakan lingkungan hidup, Setprov Sulawesi Selatan.

[31] Agus Supriadi. PT INCO, Environmental Study of Sulfur and Sulfate Concentration in Soil and Water Sorowako and its Surrounding Area, Juni 2010.

[32] PT INCO, Fuel consumption and cloud seeding activities, Januari 2011.

[33] PT INCO. Environmental Study Of Sulfur And Sulfate Concentration In Soil And Water Sorowako And Its Surrounding Area, Sorowako, 2010.

[34] Rader P., J. Augeli and S. Ahman (2000), Alstom Power FGD Technologies: $\mathrm{SO}_{2}$ Compliance for Low Rank Coals at the Lowest Life Cycle Cost, Low Rank Coal Utilization, ICS, Jakarta.

[35] Ravi K. Srivastava. (2000). U.S. Environmental Protection Agency National Risk Management Research Laboratory Research Triangle Part, NC.27711.

[36] Reuther J. J. (1989), Applied Coal Combustion Basic, The Pennsylvania State University, USA.

[37] Riyanto Marosin. 1995. Peralatan kontrol polusi udara. Teknologi Pengendalian dan Pengukuran Polusi Udara di Industri. UPT-LSDE, BPP Teknologi.

[38] Saeni, M. S.,1989. Kimia Lingkungan.

[39] Sato, T., Goro, T., Okabe, T., and Lawson, F., 2013, 'The Oxidation of Iron(Ll) Sulfate With Sulfur Dioxide and Oxygen Mixture," Bull. Chem. Soc. Jpn, 57(8), 2082-2086. 
[40] Djayanti, S., Perancangan Prototipe Alat Pengendalian Pencemaran $\mathrm{SO}_{2}$ dengan Teknologi Non Thermal Plasma. Balai Besar Teknologi Pencegahan Pencemaran Industri.

[41] Sjahrul, M., 2001, Kimia Lingkungan. Fakultas MIPA. Universitas Hasanuddin. Makassar.

[42] Smith, S. J., Andres, R., Conception, E., and Lurz, J.: Sulfur Dioxide Emissions: 1850-2000, JGCRI Report PNNL-14537, 2004.

[43] Srivastava, A., and Kumar, R., 2001, Economics Valuation of Health Impact of Air Pollution in Mumbei, Environmental Monitoring and Assessment, 75: 135-143.

[44] Sudrajad, Agung., 2006, Pencemaran Udara, Suatu Pendahuluan

[45] Valix, M., and W. H. Cheung, 2002, Effect of sulfur on the mineral phases of laterite ores at high temperature reduction, Miner. Eng. 15: 523-530.

[46] Youvial M, Sastrawinata, Yurismono (1999), Laporan Akhir Studi Kelayakan Pengendalian Emisi $\mathrm{SO}_{2}$, UPT LSDE-BPPT, Maret 1999.
[47] Yurismono H., Cahyadi, YenniWesti (2003), Pengendalian $\mathrm{SO}_{2}$ dengan Sistem Injeksi Batu Kapur pada PLTU Batubara, Laporan Akhir RUT, UPT LSDE-BPPT.

[48] Watson, J., Chow, J., Wang, X., Kohl, S., Sodeman, D., 2010. Measurement of Realworld Stack Emissions with a Dilution Sampling System (No. 010109-123109), Prepared by Desert Research Institute, Reno, NV, for Ft. McMurray, AB, Canada, Wood Buffalo Environmental Association.

[49] Xiao, H. Y., Liu, C. Q., 2002. Sources of nitrogen and sulfur in wet deposition at Guiyang, southwest China. Atmospheric Environment 36, 5121-5130.

[50] Zhang, W., P. Singh and D. M. Muir, 2000, $\mathrm{SO}_{2} / \mathrm{O}_{2}$ as an oxidant in hydrometallurgy, Miner. Eng. 13(13), 1319-1328.

[51] Zhao, F., Knights, J., Hu, Z., McGrath, S., 2003. Stable sulfur isotope ratio indicates long-term changes in sulfur deposition in the Broadbalk experiment since 1845. Journal of Environmental Quality 32, 33-39. 